\title{
The relationship between fertility and lactation characteristics in Holstein cows on United Kingdom commercial dairy farms
}

\author{
B. Albarrán-Portillo* and G. E. Pollott $\dagger^{1}$ \\ ${ }^{*}$ Centro Universitario UAEM Temascaltepec, Universidad Autónoma del Estado de México, Carretera Toluca-Tejupilco Km. 67.5. C.P. 51300, \\ México \\ †Royal Veterinary College, Royal College Street, London, NW1 OTU, UK
}

\section{ABSTRACT}

Higher milk production is commonly associated with poorer fertility in dairy cows. This study used a biological model of lactation to define more closely which characteristics of lactation were linked to increased calving interval, an easily recorded measure of fertility in commercial dairy herds. Large data sets from a national milk recording scheme in the United Kingdom, collected over a 10-yr period, were used to calculate the genetic and phenotypic correlations between calving interval and a range of lactation traits within the Holstein breed. A lactation curve was fitted to each lactation, and several characteristics of each lactation were calculated. These were used in a series of mixedmodel bivariate analyses with calving interval to derive the genetic parameters. When heifer lactation curve trait data were used, the highest genetic correlations were found with peak yield, maximum secretion potential, and total lactation milk yield $(0.59 \pm 0.06$ to 0.63 $\pm 0.05)$, reflecting the observed phenomenon of poorer fertility and higher milk production. Genetic correlations for calving interval were also calculated with the rate of increase in milk yield in early lactation $(0.46 \pm$ $0.08)$, persistency $(0.36 \pm 0.09)$, day of peak yield $(0.20$ $\pm 0.02)$, and relative cell death rate $(-0.12 \pm 0.09)$. The daily production of milk components was highly genetically correlated with calving interval, with values for fat, protein, lactose, and water being $0.73 \pm 0.15$, $0.48 \pm 0.13,0.57 \pm 0.13$, and $0.50 \pm 0.13$. With these results and breeding values derived from these analyses, 2 possible strategies were suggested for improving the relationship between milk yield and fertility in dairy cows. First, animals that break the correlations described above could be selected (e.g., bulls with high peak yield and low calving intervals). Second, animals

\footnotetext{
Received April 17, 2012.

Accepted October 5, 2012.

${ }^{1}$ Corresponding author: gpollott@rvc.ac.uk
}

with lower peak yields but better persistency could be selected to maintain total milk yield.

Key words: biological model, dairy cow, fertility, lactation curve

\section{INTRODUCTION}

The relationships between fertility and milk production traits are complex. The increase in milk production seen in many developed dairy industries during the last $20 \mathrm{yr}$ has been linked to reduced fertility, but more recently, this negative relationship has been mitigated by newer selection objectives (Walsh et al., 2011). LeBlanc (2010) has pointed out that the true underlying fertility traits are often lost when using "gross" traits, such as calving index. However, the underlying model in quantitative genetics makes no reference to the actual genes affecting a trait, but accounts for all genetic influences regardless of the underlying biology. Several authors have investigated the gross milk traits (usually 305-d milk yield and the equivalent milk components) and their link to various aspects of fertility. Kadarmideen et al. (2003) found the genetic correlations between calving interval and 305-d milk, fat, and protein yields to be $0.4,0.35$, and 0.28 , respectively. They also demonstrated very high genetic correlations between a range of fertility traits and calving interval, suggesting that calving interval is a useful proxy for several of its component traits. Using test-day (TD) yield at d 90 of lactation, Sewalem et al. (2010) found genetic correlations of 0.29 for calving-to-first service interval but lower values for nonreturn rate and the first service-to-conception interval.

Recent attempts to describe the production of milk and its components in greater depth have resulted in several new measures of milk production to describe the lactation curve. These "biological" descriptors of lactation provide a more detailed look at the aspects of the cow that affect milk production and also provide the opportunity to investigate the links between fertility and lactation characteristics. In this paper, the widely used measure of fertility, calving interval, is investi- 
gated by seeing how it is linked to various measures of milk production and milk component production by using the biological model of lactation described by Pollott (2000, 2004). Several aspects of dairy production are commonly recorded in the form of TD records or 305-d lactation measurements, but few reports are available that investigate the aspects of lactation linked to decreasing fertility levels. In this paper, the use of parameters from a biological model of lactation have allowed a more detailed investigation of which aspects of production are linked to reduced fertility. The objective of this study was to determine which key lactation characteristics, such as the parameters of the lactation curve and daily yield traits (milk, fat, protein, lactose, TS, and water), were linked to fertility, as measured by calving interval.

\section{MATERIALS AND METHODS}

\section{Data}

The basic data set used in this paper was provided by National Milk Records Ltd. (Harrogate, UK) from commercial dairy herds in the United Kingdom, as previously described by Albarrán-Portillo and Pollott (2008). Briefly, the lactations were recorded between the years 1994 and 2003. Lactations were composed of monthly TD records, ranging from 1 to 15 per lactation, and each TD record included milk yields $(\mathrm{kg} / \mathrm{d})$ and proportions of fat, protein, and lactose. Proportions of milk components for each TD were transformed into daily component yields $(\mathrm{kg} / \mathrm{d})$ by multiplying by the daily milk yield. These daily component yields were summed to give TS production. The amount of water produced per day was calculated from the difference between the daily milk yield and the daily TS production.

Lactations from the National Milk Records Ltd. (Chippenham, UK) data set were edited as follows: lactations that had their first TD record taken at more than d 80 of lactation and lactations with $<4$ TD were deleted. Subsequently, cows without pedigree information were discarded and cows aged $<20$ or $>40$ mo at first calving (AFC) were deleted. Cows in which calving intervals were $<300$ or $>600 \mathrm{~d}$ were excluded (Pryce et al., 2000).

\section{Biological Model Description}

A curve was fitted to each lactation in the data set by using the 2-parameter multiplicative biological model suggested by Pollott and Gootwine (2000). This is an alternative to the original 7-parameter multiplicative model (Pollott, 2000) because of the difficulty of fitting a model with many parameters to a lactation with few TD records and only 1 record in the accelerating phase of lactation. The 2-parameter model was as follows:

$$
M_{t}=\underbrace{\left(M S /\left\{1+a \times e^{[-0.1 \times(t-150)]}\right\}\right)}_{\mathrm{S}_{a} \times \mathrm{NDPC}} \underbrace{\left\{2-e^{[D R \times(t-150)]}\right\}}_{\mathrm{PR}},
$$

where $M_{t}$ is milk yield on day $t$ of lactation, $M S$ is the maximum secretion potential of the lactation, $a=[(1-$ $0.9999999) / 0.9999999]$, and $D R$ is the relative decline in cell numbers as the lactation progressed (Pollott and Gootwine, 2000, 2001). The model consisted of 2 logistic curves. The first curve accounted for the maximum value of the trait involved (e.g., milk) as a function of time $(t)$. Specifically, the first part of the equation estimated the maximum secretion potential (MS), which was the result of the maximum secretion rate of milk from the average cell $\left(\mathrm{S}_{a} ; \mathrm{kg} /\right.$ cell per day), combined with the total number of parenchyma cells that became active during lactation (NDPC). The second part of the equation determined the proportional reduction in cell numbers as the lactation progressed [PR; the down slope of the curve after peak yield (PY)], which was the result of the relative death rate of cells (DR) as a function of time (Pollott, 2000).

\section{Curve Fitting}

The lactation curves were fitted with the 2-parameter biological model by using an iterative nonlinear curvefitting procedure with the Statistical Analysis System program (NLIN; SAS Institute, 2003). The iterative process was begun using preliminary estimates of the parameters, for example, MS $=0.1$ to 85 (bounds $0<$ MS <85), and DR $=0.0001$ to 0.1 (bounds $-1<\mathrm{DR}$ $<1)$. The best-fit lactation curve was obtained when the difference between the residual sums of squares in successive iterations was $<10^{-6}$.

\section{Lactation Curve Traits}

Pollott (2000) described how to calculate several lactation curve characteristics from the biological model to augment the 2 parameters MS and DR. These were the daily change in yield at the midpoint between the start and peak of lactation (GM), PY, day of PY (DP), the daily loss of yield at the midpoint from PY to the end of lactation (DLM; equivalent to persistency), calculated total milk yield (CTMY), and total milk yield (TMY; after Sargent et al., 1968). 
Table 1. Pedigree information and distribution of lactations by parity number for the data sets used in these analyses

\begin{tabular}{lr}
\hline Item & $\mathrm{n}$ \\
\hline Curve trait data set (data set 1) & \\
Animal type & \\
Sires & 4,416 \\
Dams & 59,649 \\
Heifers & 69,319 \\
Total & 133,384 \\
No. of lactations by parity (data set 2) & \\
First lactations & 69,319 \\
Second lactations & 46,439 \\
Third lactations & 30,149 \\
Four plus lactations & 30,850 \\
Total lactations & 176,757 \\
Milk component trait data set (data set 3) & \\
Animal type & \\
Sires & 3,427 \\
Dams & 38,546 \\
Heifers & 43,698 \\
Total & 85,671 \\
No. of lactations by parity (data set 4) & \\
First lactations & 43,698 \\
Second lactations & 25,624 \\
Third lactations & 14,919 \\
Four plus lactations & 12,351 \\
Total lactations & 96,592 \\
\hline
\end{tabular}

A data set containing 69,319 lactations from firstcalving cows, consisting of 8 lactation curve traits plus the calving interval, was compiled to investigate the relationships between the lactation curve traits and calving interval (data set 1). This represents a subset of the records described by Albarrán-Portillo and Pollott (2008) for which a subsequent calving interval was available. For the genetic analysis, the pedigree file contained 4,416 sires and 59,649 dams of the cows in the data set. Table 1 shows a pedigree summary as well as the number of lactations according to the parity number used. An additional data set designed for a repeatability analysis was also constructed by including the subsequent records of the above-mentioned heifers as older animals (data set 2 ).

\section{Milk Components}

A further data set containing TD records of yield traits (i.e., milk, fat, protein, and lactose; $\mathrm{kg} / \mathrm{d}$ ) was complemented by calculating TS and water contents (data set 3). The average number of TD per lactation in this data set was 10, ranging from 4 to 15 .

Originally, it was intended to include all TD per lactation in the genetic analysis of milk component traits. However, it was not possible to run such an analysis when including all TD because of the large size of the data set in relation to the computing facilities available. Therefore, to include as many lactations as possible in the analysis, it was decided to reduce the number of TD to 1 per lactation and fit week of lactation as a covariate in the model. This single TD per lactation was randomly selected for the analysis and was within the range of wk 10 to 20 of lactation, the approximately linear downslope phase of lactation. The average week of the TD in the resulting data set was wk 14. Hence, results outlining component traits corresponded to wk 14 of lactation.

The component-traits data set included 43,698 first lactations. This was somewhat less than the number of cows used in data set 1 because of the requirement for a complete set of milk component data to be available. The pedigree file of this data set contained 3,427 sires and 38,546 dams. Table 1 shows a summary of the pedigree files from data sets 1 and 3 (i.e., lactation curve traits and milk yield traits for heifers), as well as the summary of lactations, by parity, included in the repeatability analyses (data sets 2 and 4) when using the later records from the heifers as well.

\section{Genetic Analyses}

An animal model was used to estimate the heritability of the lactation curve traits, yield traits, and calving interval. Univariate analyses were carried out with ASReml (Gilmour et al., 2009), using models that followed the results of Albarrán-Portillo and Pollott (2008).

The univariate animal model for the heifer data set 1 was

$$
Y_{i j k l m}=\mu+H Y S_{i}+A F C_{j}+L l_{k}+a_{l}+e_{i j k l m},
$$

where $Y_{i j k l m}$ is the dependent variable, $\mu$ is the overall mean, $H Y S_{i}$ is the fixed effect of herd-year-season of calving, $A F C_{j}$ is the covariate age at first calving (mo), $L l_{k}$ is the covariate lactation length (d), $a_{l}$ is the random genetic effect, used to estimate the additive genetic variance, and $e_{i j k m l}$ is the random residual effect. Model 2 was used for all traits except calving interval; in this case, lactation length was not used as a covariate because of its high correlation with calving interval.

Genetic and phenotypic correlations of calving interval with lactation curve traits and milk yields traits were estimated by using bivariate analyses in ASReml (Gilmour et al., 2009). The appropriate models derived for each trait from the univariate analyses were used in the bivariate analyses.

To estimate the permanent environmental variance and the repeatability of each trait, univariate analyses of repeated records (data set 2) were performed using ASReml with model 3: 


$$
\begin{aligned}
Y_{i j k l m n}= & \mu+H Y S_{i}+A F C_{j}+L N O_{k}+L L_{l} \\
& +a_{m}+R p_{m n}+e_{i j k l m n o} .
\end{aligned}
$$

Most of the terms in model 3 were defined as for model 2 except for $L N O_{k}$, the effect of lactation number, and $R p_{m n}$, the random permanent environmental effect of cows. For the corresponding analyses of milk component traits (data sets 3 and 4), an additional covariate was used in the model to account for the week of lactation of the TD records randomly selected for use in the analyses, as discussed above.

In all analyses, the heritability was calculated as the ratio of the additive genetic variance to phenotypic variance, the repeatability was calculated as the ratio of the sum of the additive and permanent environmental variance to the phenotypic variance, and their standard errors were calculated as described by Gilmour et al. (2009). Genetic and phenotypic correlations were estimated from bivariate analyses in ASREML (Gilmour et al., 2009) between calving interval and lactation traits by using the appropriate equations for each pair of traits from data sets 1 and 3 (i.e., heifer characteristics).

\section{RESULTS}

Table 2 shows the mean and standard deviation of the heifer traits analyzed. The average MS was 29.4 $\mathrm{kg} / \mathrm{d}$, whereas PY was $28.0 \mathrm{~kg} / \mathrm{d}$ and was close to the MS. Day of peak yield was reached early in lactation on $\mathrm{d} 34$. The rate of increase in milk yield midway between the start and peak of lactation was $148 \mathrm{~g} / \mathrm{d}$. The relative rate of decline in cell numbers after parturition was 0.001 , whereas persistency was $50.1 \mathrm{~g} / \mathrm{d}$. The

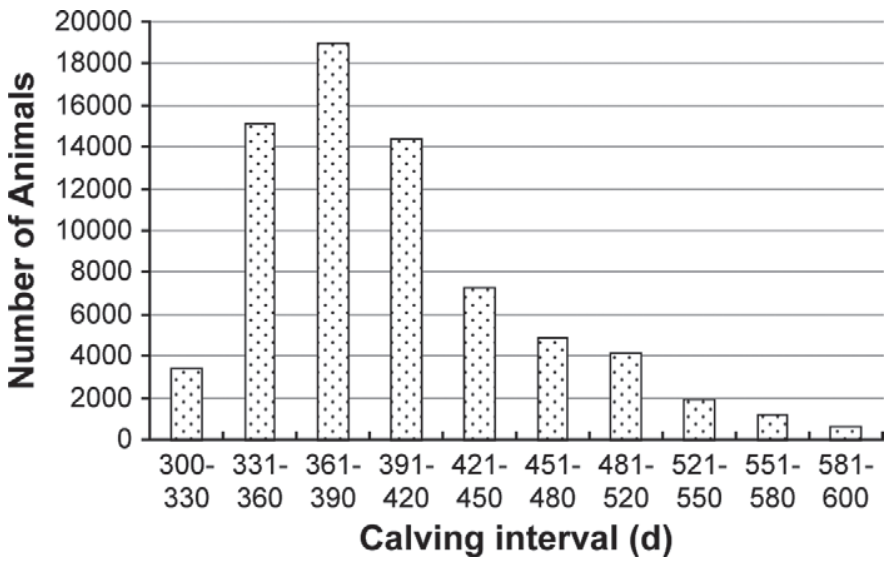

Figure 1. Distribution of calving intervals used in this study from data set 1 .

CTMY and TMY were 7,354 and 7,255 kg, respectively, showing how well the biological model can be used to predict TMY.

The average daily milk yield adjusted for week of lactation (average wk 14) was $26.7(\mathrm{~kg} / \mathrm{d})$, containing $1.09 \mathrm{~kg} / \mathrm{d}$ of fat, $0.95 \mathrm{~kg} / \mathrm{d}$ of protein, $0.94 \mathrm{~kg} / \mathrm{d}$ of lactose, $3.47 \mathrm{~kg} / \mathrm{d}$ of TS, and $23.3 \mathrm{~kg} / \mathrm{d}$ of water. Contents per kilogram of milk were $40.8,35.5$, and $53.1 \mathrm{~g} / \mathrm{kg}$ of fat, protein, and lactose, respectively, which resulted in $129.8 \mathrm{~g} / \mathrm{kg}$ of TS. Water represented $87 \%$ of milk production.

Figure 1 shows the distribution of calving intervals in the data set. The average calving interval was $399 \pm 59$ d. Most of the observations fell between 330 and $420 \mathrm{~d}$, representing $67 \%$ of the calving intervals. Age at first calving had an average of $28.4 \pm 5.74$ mo and mean lactation length was $321 \pm 72.1 \mathrm{~d}$.

Table 2. Means and standard deviations for lactation traits

\begin{tabular}{lcc}
\hline Item & Mean & SD \\
\hline Curve trait (data set 1) & & \\
Maximum secretion potential $(\mathrm{kg} / \mathrm{d})$ & 29.4 & 5.76 \\
Daily yield change in early lactation $(\mathrm{g} / \mathrm{d})$ & 148 & 5.44 \\
Peak yield $(\mathrm{kg})$ & 28.0 & 7.17 \\
Day of peak yield (d) & 34.3 & $4.00 \mathrm{E}-04$ \\
Relative cell death rate & $1.09 \mathrm{E}-03$ & 41.7 \\
Persistency (g/d) & 50.1 & 1,949 \\
Calculated total milk yield $(\mathrm{kg})$ & 7,354 & 1,937 \\
Total milk yield (kg) & 7,255 & 59.5 \\
Calving interval (d) & 399 & 6.01 \\
Milk and milk component yields (data set 3) & & 0.24 \\
Milk $(\mathrm{kg} / \mathrm{d})$ & 26.7 & 0.28 \\
Fat $(\mathrm{kg} / \mathrm{d})$ & 1.09 & 0.18 \\
Protein $(\mathrm{kg} / \mathrm{d})$ & 0.95 & 0.65 \\
Lactose $(\mathrm{kg} / \mathrm{d})$ & 0.94 & 5.51 \\
TS $(\mathrm{kg} / \mathrm{d})$ & 3.47 & \\
Water $(\mathrm{kg} / \mathrm{d})$ & 23.3 & \\
\hline
\end{tabular}


Table 3. Heritabilities $\left(\mathrm{h}^{2}\right)$ and standard errors of curve traits and calving interval

\begin{tabular}{lcc}
\hline Curve trait (data sets 1 and 3 ) & $\mathrm{h}^{2}$ & $\mathrm{SE}$ \\
\hline Maximum secretion potential & 0.34 & 0.02 \\
Daily yield change in early lactation & 0.13 & 0.01 \\
Day of peak yield & 0.03 & 0.01 \\
Peak yield & 0.36 & 0.02 \\
Relative cell death rate & 0.13 & 0.01 \\
Persistency & 0.10 & 0.01 \\
Calculated total milk yield & 0.26 & 0.01 \\
Calving interval & 0.03 & 0.01 \\
Milk & 0.22 & 0.01 \\
Fat & 0.16 & 0.01 \\
Protein & 0.23 & 0.01 \\
Lactose & 0.26 & 0.01 \\
TS & 0.21 & 0.01 \\
Water & 0.21 & 0.01 \\
\hline
\end{tabular}

\section{Heritability of Heifer Traits}

The heritability estimates, and standard errors, of the traits analyzed are shown in Table 3 . Peak yield and MS had similar heritability values $(\sim 0.35)$, the highest values found in these data. The 2 measures of lactation milk yield had the next highest values $(\sim 0.26)$, followed by most of the milk and milk component traits $(\sim 0.22)$ and fat yield (0.16). The 2 cell rate change traits had identical heritabilities (0.13), with persistency slightly lower (0.10). Calving interval and DP had very low heritabilities (0.03) but were both greater than zero.

\section{Genetic and Phenotypic Correlations of Heifer Traits}

The full set of genetic and phenotypic correlations between the lactation curve traits was reported in Albarrán-Portillo and Pollott (2008) from a larger data set that included the data analyzed here. Consequently, the correlations between all the lactation curve traits are not shown here. Briefly, the genetic correlations between MS, PY, CTMY, and TMY were close to unity. The relative decline in cell numbers (DR) was negatively correlated with key traits such as MS, DP, PY, CTMY, and TMY. Persistency (DLM) was genetically correlated with all traits, with the exception of DP, such that higher values of yield were associated with a reduction in persistency. The phenotypic correlations were lower than the genetic correlations and in general followed the same trend as genetic correlations.

Table 4 shows the genetic and phenotypic correlations between calving interval and lactation curve traits. Maximum secretion potential, PY, and both TMY were strongly correlated with calving interval, at the genetic level, such that longer calving intervals were associated with higher yields. Longer calving intervals were also genetically associated with higher values of DLM, and thus with less persistency, and were only weakly linked to the relative rate of decline in cell numbers.

Phenotypic correlations of calving interval with MS, $\mathrm{DP}$, and PY were very low $(<0.06)$. Calving interval had similar phenotypic correlations with CTMY and TMY (0.54). Finally, the phenotypic correlations of calving interval with GM, DR, and DLM were low and negative.

Table 5 shows the genetic and phenotypic correlations and their standard errors between calving interval and daily milk component traits. All genetic correlations, with the exception of protein, were high $(>0.50)$. Fat was the component with the highest genetic correlation (0.73) among the yield traits. The rest of the genetic correlations were similarly high, ranging from 0.51 (milk) to 0.57 (lactose and TS). Phenotypic correlations between calving interval and the component traits were all very low, ranging from 0.01 (protein) to 0.03 (fat).

\section{Genetic Parameters from All Age Groups}

Table 6 shows the heritability, permanent environmental variance proportion, and repeatability of curve traits and calving interval derived from the repeatability analyses. Traits from the first part of the lactation curve (MS, GM, and PY) had similar and low values for permanent environmental variance proportion, with the exception of DP, for which the permanent environmental variance proportion was almost twice as high as the heritability. From the second part of the lactation curve, the permanent environmental variance proportions of DR, DLM, CTMY, and TMY were 0.08, $0.07,0.15$, and 0.15 , respectively; in these traits, the permanent environmental variance proportion was al-

Table 4. Genetic and phenotypic correlations between calving interval and lactation curve traits from data set $1^{1}$

\begin{tabular}{lcccccccc}
\hline Correlation & MS & GM & DP & PY & DR & DLM & CTMY & TMY \\
\hline Genetic & 0.59 & 0.46 & 0.20 & 0.59 & -0.12 & 0.36 & 0.63 & 0.62 \\
SE & 0.06 & 0.08 & 0.02 & 0.06 & 0.09 & 0.09 & 0.05 \\
Phenotypic & 0.03 & -0.08 & 0.06 & 0.04 & -0.18 & -0.09 & 0.54 \\
SE & 0.004 & 0.004 & 0.004 & 0.004 & 0.004 & 0.004 & 0.002 & 0.54 \\
\hline
\end{tabular}

${ }^{1} \mathrm{MS}=$ maximum secretion potential; GM $=$ daily yield change in early lactation; DP $=$ day of peak yield; PY = peak yield; DR $=$ relative cell death rate; $\mathrm{DLM}=$ persistency; $\mathrm{CTMY}=$ calculated total milk yield; TMY $=$ total milk yield. 
Table 5. Genetic and phenotypic correlations between calving interval and daily milk component traits from data set 3

\begin{tabular}{lllcccc}
\hline Correlation & Milk & Fat & Protein & Lactose & TS & Water \\
\hline Genetic & 0.51 & 0.73 & 0.48 & 0.57 & 0.57 & 0.50 \\
SE & 0.13 & 0.15 & 0.13 & 0.13 & 0.13 & 0.13 \\
Phenotypic & 0.02 & 0.03 & 0.01 & 0.02 & 0.02 & 0.02 \\
SE & 0.002 & 0.002 & 0.002 & 0.002 & 0.002 & 0.002 \\
\hline
\end{tabular}

most half that of the heritability. The traits with higher repeatability values were MS (0.31), DP (0.41), DR (0.26), DLM (0.22), CTMY (0.41), and TMY (0.42). The contribution of the permanent environmental variance proportion to the repeatability of GM and PY was lower than for the rest of the traits, resulting in repeatability estimates of 0.22 and 0.33 , respectively.

The repeatability of calving interval was quite low (0.08), even when the permanent environmental variance proportion was almost twice that of the heritability. The repeatability values of milk component traits were $0.29,0.19,0.23,0.27,0.21$, and 0.29 for milk, fat, protein, lactose, TS, and water, respectively. The permanent environmental variances were 0.09, 0.04, 0.04, 0.06, 0.04, and 0.09 for milk, fat, protein, lactose, TS, and water, respectively.

The genetic correlations between calving interval and the lactation curve traits are shown in Table 7 for second calvers and for all animals other than heifers. These 2 sets of correlations were mostly similar, with the exceptions of the rate of change in cell numbers late in lactation and the TMY traits. The second calvers had a higher genetic correlation with calving interval than did the older animals ( -0.8 vs. -0.27$)$ but a lower TMY genetic correlation ( 0.38 vs. 0.53 ). A comparison of the heifer genetic correlations (Table 4) with those from older animals showed that the heifer correlations were somewhat higher than the second calver correlations, particularly in the milk yield traits.

\section{DISCUSSION}

\section{Calving Interval as a Measure of Fertility}

Calving interval is a widely used measure of fertility because calving dates are commonly available in milk recording schemes and calving interval represents the sum total of events ultimately leading to successful calving. Calving interval can be calculated from these dates and analyzed to assess the fertility of cows kept on commercial dairy farms. Calving interval has been used in several studies that examined the genetics of fertility and its relationship with other commonly recorded production traits. More detailed studies of the components of calving interval (days to first service, conception rates, nonreturn rates, days to successful conception, gestation length) are often informative about the relationships between fertility traits, but many such components are not widely recorded or available in large enough numbers to allow accurate genetic relationships with production traits to be established without a considerable amount of work to put sources of data together. One such study by Sewalem et al. (2010) found low genetic correlations between d 90 TD milk yield and nonreturn rate $(-0.13)$, days to first service (0.29), and days from first service to conception (0.12). LeBlanc (2010) highlighted the pitfalls of using calving interval as a measure of fertility. Calving interval and milk yield are bound to be highly correlated in a detrimental manner, and LeBlanc (2010) recommended using multivariate survival analysis of reproductive traits as the only true method for measuring individual cow fertility. Although this approach undoubtedly provides an unbiased estimate of a cow's fertility, it is not currently feasible with commercial dairy records in most situations. In addition, the quantitative genetic approach used here is to include all genetic influences on a trait regardless of their origin. Hence, the indirect effect of milk yield is a valid influence on calving interval in this setting.

Table 6. Heritability $\left(h^{2}\right)$, permanent environmental variance proportion $\left(\mathrm{c}^{2}\right)$, and repeatability (r) of curve traits, calving interval, and yield traits from data sets 2 and $4^{1}$

\begin{tabular}{lccc}
\hline Trait & $\mathrm{h}^{2}$ & $\mathrm{c}^{2}$ & $\mathrm{r}$ \\
\hline Maximum secretion potential & 0.26 & 0.04 & 0.31 \\
Daily yield change in early lactation & 0.18 & 0.04 & 0.22 \\
Day of peak yield & 0.13 & 0.28 & 0.41 \\
Peak yield & 0.27 & 0.05 & 0.33 \\
Relative cell death rate & 0.18 & 0.08 & 0.26 \\
Persistency & 0.15 & 0.07 & 0.22 \\
Calculated total milk yield & 0.26 & 0.15 & 0.41 \\
Total milk yield & 0.26 & 0.15 & 0.42 \\
Calving interval & 0.03 & 0.05 & 0.08 \\
Milk & 0.21 & 0.09 & 0.29 \\
Fat & 0.15 & 0.04 & 0.19 \\
Protein & 0.19 & 0.04 & 0.23 \\
Lactose & 0.21 & 0.06 & 0.27 \\
TS & 0.17 & 0.04 & 0.21 \\
Water & 0.20 & 0.09 & 0.29 \\
\hline
\end{tabular}

${ }^{1}$ Standard error $\mathrm{h}^{2} \geq 0.003$ to $\leq 0.001 ; \mathrm{SE} \mathrm{c}^{2} \geq 0.004$ to $\leq 0.009 ; \mathrm{SE} \mathrm{r}$ $\geq 0.003$ to $\leq 0.004$. 
Calving intervals reported in the literature range from 368 d (Evans et al., 2006) to 398 d (Haile-Mariam et al., 2003), but recent work from the Scottish Agricultural College's Langhill herd found calving interval to be $403 \mathrm{~d}$ (Pollott and Coffey, 2008). The mean of 399 $\mathrm{d}$ found in the current study masks a trend in the data for an increase over the period of study. A change in mean calving interval was observed over a 10 -yr period, from $393 \pm 2.46 \mathrm{~d}$ to $412 \pm 0.32 \mathrm{~d}$ in this data set, and reflects that of Hare et al. (2006) for a range of breeds in the United States.

\section{Biological Model of Lactation and Fertility}

Pollott (2000) proposed a biological model to study the lactation curve. The biological model describes parameters of the curve in terms of secretory cell differentiation in early lactation, cell death rate after parturition, and changes to milk secretion rate during lactation. Therefore, the output parameters from this model have a biological basis that explains the lactation in terms of the number of differentiated cells during lactation, the numbers of cells dying throughout lactation, and the secretion rate of milk per active cell. The parameters from the model by Pollott (2000) cover those described by the widely used model of Wood (1967), as well as some newly proposed parameters. Pollott and Gootwine (2001) used the biological model to estimate the genetic characteristics of the complete lactations of Awassi sheep. They showed the heritability of the lambing interval to be very low $(0.04 \pm$ 0.02 ), and it was found to have genetic correlations with production and curve parameter traits close to zero, probably because of the particular management practices in the flock.

\section{Heritability of Lactation Curve Traits and Calving Interval}

The trait with the highest heritability (0.36) was PY, which was higher than the 0.27 from a similar data set in Albarrán-Portillo and Pollott (2008), and higher than the 0.30 estimated by Pollott (2009) because in the studies by both Albarrán-Portillo and Pollott (2008) and Pollott (2009), the heritability of MS was close to the heritability of PY (0.36). The heritability of PY was high compared with those reported by Farhangfar (2002) and Pollott (2009) and was within the range reported by Zwald et al. (2003). The heritability of GM was 0.13 . This relates to the same trait as parameter $b$ in Wood's model, and was higher than the estimates by Shanks et al. (1981) and Farhangfar (2002), but was lower than that by Varona et al. (1998), who reported a heritability of 0.17 . Day of peak yield is a trait usually reported with low heritability. The heritability estimate in this study was 0.03 and was lower than the 0.09 , 0.09, 0.10, and 0.06 reported by Shanks et al. (1981), Muir et al. (2004), Farhangfar (2002), and Pollott (2009), respectively. Persistency was found to have a heritability of 0.10 and was low compared with other reports in the literature (Shanks et al., 1981; Batra et al., 1987; Jamrozik et al., 1998; Zwald et al., 2003; Muir et al., 2004; Pollott, 2009). However, Farhangfar (2002) also found a low value of 0.08 . Heritability estimates of CTMY and TMY were 0.26 and 0.27 and ranged within the values reported in the literature (Shanks et al., 1981; Batra et al., 1987; Zwald et al., 2003; Muir et al., 2004; Silvestre et al., 2005; Ben Gara et al., 2006).

Several reports have given the heritability of calving interval, and all these reports have concluded that calving interval has low heritability. The heritability of the calving interval reported here was 0.03 and was lower than the 0.10, 0.09, 0.04, and 0.07 reported by Campos et al. (1994), Pryce et al. (1999), Olori et al. (2002), and Muir et al. (2004). Other authors found values similar to those reported here, such as 0.02 (Pryce et al., 2000), 0.01 (Pryce et al., 2001), 0.02 (Pryce et al., 2002), 0.03 (Haile-Mariam et al., 2003), 0.02 (Kadarmideen et al., 2003), 0.03 (Wall et al., 2003), and 0.03 (Banos et al., 2005 ). Thus, the data in this study were typical of reports found in the literature.

\section{Milk Yield and Fertility}

Genetic selection for increased milk yield has often been linked to a deterioration in the fertility of dairy

Table 7. Genetic correlations between calving interval and lactation curve traits from data set 2 split into second calvers and all older animals ${ }^{1}$

\begin{tabular}{lllllrlrc}
\hline Correlation & MS & GM & DP & PY & DR & DLM & CTMY & TMY \\
\hline Second calvers & 0.46 & 0.34 & 0.08 & 0.46 & -0.08 & 0.17 & 0.37 & 0.38 \\
SE & 0.06 & 0.07 & 0.06 & 0.06 & 0.06 & 0.08 & 0.05 & 0.05 \\
All older animals & 0.53 & 0.34 & 0.11 & 0.54 & -0.27 & 0.12 & 0.53 & 0.53 \\
SE & 0.04 & 0.04 & 0.05 & 0.04 & 0.04 & 0.05 & 0.03 & 0.03
\end{tabular}

${ }^{1} \mathrm{MS}=$ maximum secretion potential; $\mathrm{GM}=$ daily yield change in early lactation; $\mathrm{DP}=$ day of peak yield; PY = peak yield; $\mathrm{DR}=$ relative cell death rate; DLM = persistency; CTMY = calculated total milk yield; TMY $=$ total milk yield. 
cows during the last 2 or 3 decades. One of the earliest reports was by Wood and Wilson (1983), who analyzed the lactations of a group of the highest yielding Friesian-Holstein cows in the United Kingdom at that time. They showed that the calving intervals of these cows were $9 \mathrm{~d}$ longer than average. High yields were explained by the use of high-genetic-merit sires and the improvement of herd management practices. They also found a negative effect of high milk production on the incidence of diseases. Since then, an increasing number of reports from several countries have been published showing the decline in fertility associated with selection for milk production (for a review, see Walsh et al., 2011), although recent broader selection goals appear to be reversing this trend (Crowe, 2007; Norman et al., 2009). Incidentally, the work of Hare et al. (2006) demonstrated that the increasing calving interval is a characteristic of many breeds in the United States, not just Holsteins. Clearly, longer calving intervals are related to longer lactations because the average dry period in the United Kingdom, for example, has remained at approximately $62 \mathrm{~d}$ for the last $10 \mathrm{yr}$ (M. P. Coffey, Scottish Agricultural College, Edinburgh, UK; personal communication).

General agreement exists that calving intervals have been unfavorably affected by the increase in the genetic potential of dairy cows for milk production (Pryce et al., 2000; Olori et al., 2002; Kadarmideen et al., 2003; Banos et al., 2005). Reproductive parameters that reflect the reproductive status of dairy cows, such as days to first observed estrus and the start of luteal activity, have been found to be delayed in high-genetic-merit cows by 21 and $11 \mathrm{~d}$, respectively. These resulted in a longer days-open period (99 d) than that of low-genetic-merit cows (91 d; Fulkerson et al., 2001). Comparing reproductive performance in a line of cows highly selected for milk production with a line reflecting the average genetic merit of UK herds, Pollott and Coffey (2008) showed that the selected cows commenced cycling $5 \mathrm{~d}$ later and had their first heat $14 \mathrm{~d}$ later than animals of average genetic merit. Lucy (2001) estimated that for every $100-\mathrm{kg}$ increase in milk yield, an increase of $1 \mathrm{~d}$ occurred from calving to conception (open days), a trait closely related to calving interval. The high proportion of milk produced in the first third of lactation has been associated with a reduced rate of pregnancy to first service (Buckley et al., 2003).

The genetic correlations between calving interval and many lactation curve parameters reported here were unfavorable in the sense that increases in production were associated with an increased calving interval, equivalent to poorer fertility. The only exceptions were DR (the decline in cell numbers from parturition to the end of lactation independently from the PY), DP, and, to a lesser extent, persistency. The high genetic correlations between calving interval and both heifer TMY traits $(\sim 0.62)$ reflect the widely reported relationship between increased milk yield and lower fertility (Pryce et al., 1999, 2000; Wall et al., 2005). This negative relationship was observed despite adjusting the production traits for lactation length, a trait highly linked to calving interval. Similar relationships were seen between calving interval and MS and PY; both traits were highly related to TMY (Albarrán-Portillo and Pollott, 2008). Because MS consists of the number of secretory cells in the mammary gland and the milk secretion rate per cell (Pollott, 2000), it is likely that one or both of these lactation characteristics are linked to declining fertility in dairy herds. By contrast, the rate of decline in cells numbers (DR) and the persistency of lactation had much smaller or virtually nonexistent correlations with calving interval. This reflects both the time in lactation when these 2 characteristics have an effect (i.e., late lactation) and the fact that cows are often pregnant by this time. This contrasts with an earlylactation trait, such as GM, and the rate of increase in milk yield between the start and peak of lactation, which was highly related to lower fertility as well. It is interesting that the DP was only moderately correlated with calving interval such that later peaks were associated with shorter calving intervals.

The high correlations between the TMY traits and calving interval were also seen at the phenotypic level (0.54), but all other phenotypic correlations were close to zero or slightly negative. This contrasts with the study by Kadarmideen et al. (2003), who found phenotypic correlations of 0.20 and 0.22 for calving interval with 305-d fat and protein yield. Thus, the strong genetic link between calving interval and many of the early-lactation traits was not always seen at the phenotypic level for most traits.

The genetic correlations between calving interval and milk component yields were also unfavorable, ranging from 0.48 (protein) to 0.73 (fat). The correlations of calving interval with milk and protein were within the ranges reported by Campos et al. (1994), Haile-Mariam et al. (2003), Kadarmideen et al. (2003), and Muir et al. (2004). However, none of these studies reported a higher correlation than the one found in this study (0.73) between calving interval and fat production.

Phenotypically, calving interval and milk components were uncorrelated because they were all approximately zero. Pryce et al. (2002) reported a negative phenotypic correlation between calving interval and milk $(-0.03)$. Other than that, phenotypic correlations between calving interval, milk, fat, and protein 
were within the ranges reported by Kadarmideen et al. (2000, 2003) and Royal et al. (2002). Levels of milk protein have been related to reproductive performance. Fulkerson et al. (2001) associated low levels of protein $(<2.89 \%)$ with a negative energy balance, resulting in poor reproductive performance. Regarding fat results, de Vries and Veerkamp (2000) suggested that changes in fat percentage are a very good indicator of energy balance, and they concluded that weekly changes in fat percentages (from wk 2 to 15) were highly correlated with energy balance. Because of this, changes in fat percentages in early lactation are good indicators of energy balance, making it possible to use them to assess the energy balance of cows at risk of poor reproductive performance.

\section{Selection for Improved Fertility Without Loss of Milk Yield}

Genetic selection for increased milk yield has directly (because of selection) or indirectly (because of energy balance) affected some characteristics of the lactation curve and milk composition. It has been established that selection for higher milk yields and its components (fat, protein, and lactose) has negatively affected the proportions of these components (Kelm et al., 2000). Lactation curve parameters, such as DP, PY, and persistency, have been affected by selection for higher milk yield. For instance, the higher the PY, the lower the level of persistency of lactation; the later the DP, the better the persistency (Muir et al., 2004). The level of PY largely determines TMY (Batra et al., 1987; Buckley et al., 2003); the higher the PY, the higher the TMY. More recent studies suggest that fertility is being improved by selection for the commercially recorded fertility traits (e.g., calving interval). The potential for this can be illustrated by using a plot of univariate EBV for calving interval and MS, calculated as part of the analyses reported here by using model 2 on data set 1 (Figure 2). Although the general trend is for an increase in MS as calving interval increases, the genetic correlation was 0.59 in data set 1 , and bulls can be found that break this trend. Toward the top left quadrant of Figure 2, bulls have EBV for lower calving

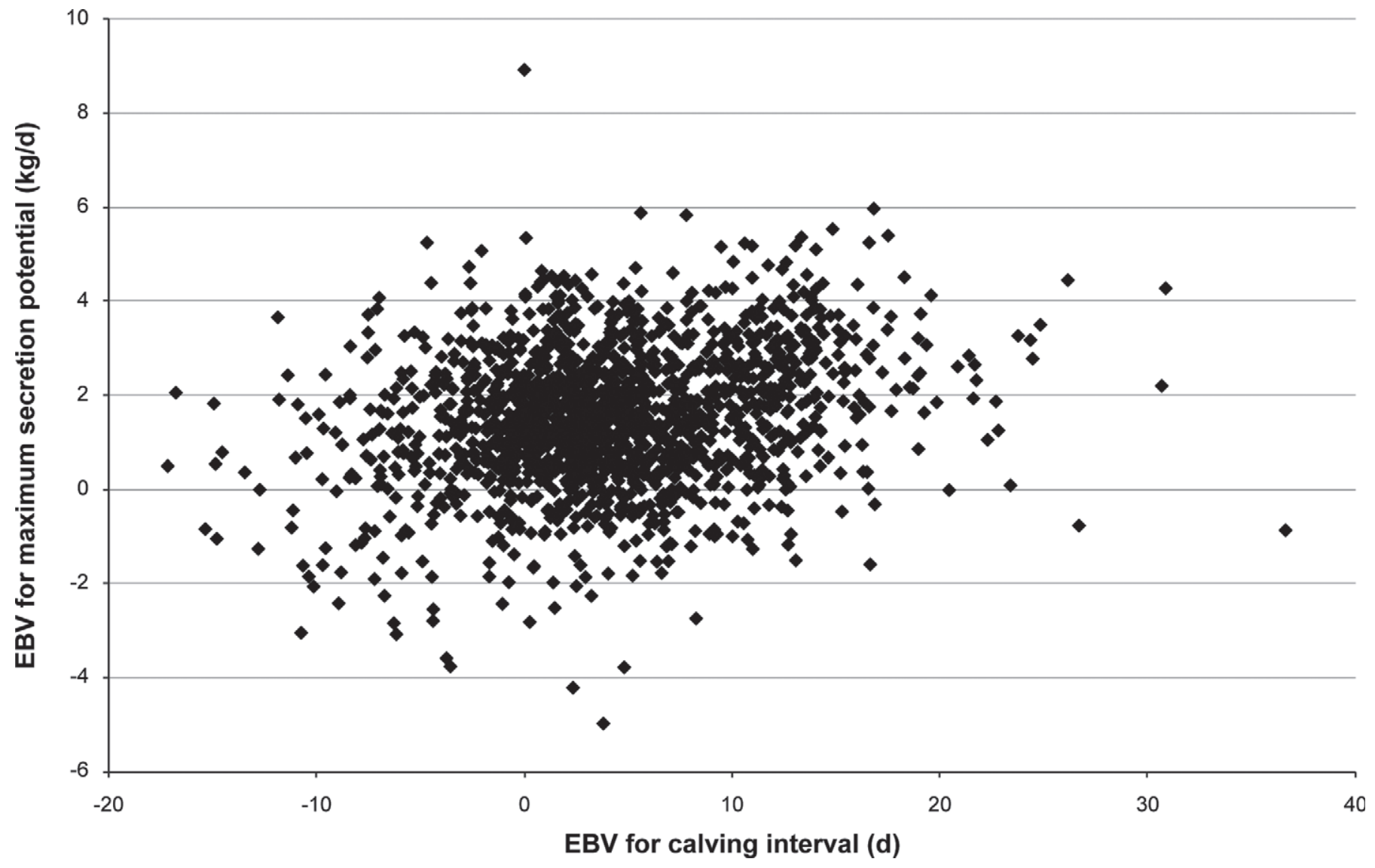

Figure 2. Plot of EBV for maximum secretion potential $(\mathrm{kg} / \mathrm{d})$ against EBV for calving interval for the bulls used in data set 1. 
intervals (improved fertility) but also relatively high MS, indicative of higher milk yield.

An alternative way to improve fertility without sacrificing TMY would be to improve persistency or reduce the relative death rate of cells. It is possible to calculate the trade-off between persistency and PY for any given $305-\mathrm{d}$ milk yield by using the mean trait and parameter values shown in Table 1. For every $10 \mathrm{~g} / \mathrm{d}$ improvement in persistency in the average cow from this study, it would be possible to maintain the same $305-\mathrm{d}$ milk yield at a $1.2 \mathrm{~kg} / \mathrm{d}$ lower PY. Because PY was found to be highly correlated with calving interval, this should lead to an improvement in fertility.

\section{The Biology of Lactation and Fertility}

Previous work (Albarrán-Portillo and Pollott, 2008) has demonstrated the very close genetic relationships between MS and PY such that it is possible to consider them the same trait. It is not surprising that they were also closely linked to TMY and the rate of increase in milk production in early lactation. The only lactation curve parameter not linked to these traits was the rate of cell death in late lactation and, to a lesser extent, persistency. A similar pattern of relationships was seen for the genetic correlations involving calving interval; the highest correlations were with PY, MS, and the milk yield traits. Persistency-related traits were less than or not correlated with calving interval. Considering the milk component traits as well, most had similar genetic correlations with calving interval as the yield traits, with the main exception being fat yield, which was more highly correlated. This implies that animals genetically disposed to longer calving intervals also produce milk with a higher fat content.

Although the current study did not attempt to investigate the genetic links between the traits studied here, a growing number of studies are attempting to do this by using SNP analysis. Work by Banos et al. (2008) and Oikonomou et al. (2009) examined small groups of SNP in the leptin, DGAT1 (diacylglycerol acyltransferase 1), and growth hormone genes, and they linked genotypes at these SNP with various differences in performance. Similar studies with 30 SNP located in leptin and other genes were also reported by Clempson et al. (2011a,b, 2012). Although these are by no means a complete picture of the genetic relationships between the traits, they do give us some idea of the possible links between them. For example, Oikonomou et al. (2009) demonstrated significant allele substitution effects for several reproductive traits by using both the DGAT1 and a growth receptor gene; the alleles associated with a decrease in reproductive performance were also linked to increased milk production and fat deposition. Similar findings were reported by Clempson et al. (2011a), in which allelic variation in the NPY1 (neuropeptide Y1) leptin gene SNP was associated with differences in both reproductive performance and 305-d milk yield. Clempson et al. (2011b, 2012) also reported similar findings for the mitochondrial transcription factor gene TFAM3 (transcription factor A, mitochondrial 3) and SNP in the IGFBP2 (IGF-binding protein 2) gene. Genome-wide studies, such as those reported by Bolormaa et al. (2010) and Pryce et al. (2010), have the potential to provide much information of the type alluded to above, but unfortunately, the authors did not report actual allele substitution effects for fertility and production traits.

\section{CONCLUSIONS}

The use of a biological model of lactation in conjunction with a measure of fertility allowed a more in-depth analysis of the features of increased lactation performance associated with reduced fertility. Earlylactation features, such as the PY and the fat content of milk, are closely linked to poorer fertility. The use of selection methods to overcome this problem could involve selection for bulls with atypical fertility-milk yield relationships or selection for lower PY and higher persistency, or both.

\section{ACKNOWLEDGMENTS}

The first author acknowledges the financial support of the National Council of Science and Technology (CONACyT, Mexico City, Mexico) and the Autonomous University of Mexico State (UAEMEX, Toluca, Mexico) toward his PhD program. National Milk Records Ltd. UK (Chippenham, UK) provided the data for this study and is gratefully acknowledged. The Sustainable Livestock Systems Group of the Scottish Agricultural College, Edinburgh, are acknowledged for the use of their facilities, in particular to Geoff Simm, Mike Coffey, Raphael Mrode, Eileen Wall, and Sue Brotherstone, of Edinburgh University, for their help during the genetic analyses.

\section{REFERENCES}

Albarrán-Portillo, B., and G. E. Pollott. 2008. Genetic parameters derived from using a biological model of lactation on records of commercial dairy cows. J. Dairy Sci. 91:3639-3648.

Banos, G., S. Brotherstone, and M. P. Coffey. 2005. Genetic profile of total body energy content of Holstein cows in the first three lactations. J. Dairy Sci. 88:2616-2623.

Banos, G., J. A. Woolliams, B. W. Woodward, A. B. Forbes, and M. P. Coffey. 2008. Impact of single nucleotide polymorphisms in leptin, 
leptin receptor, growth hormone receptor, and diacylglycerol acyltransferase (DGAT1) gene loci on milk production, feed, and body energy traits of UK dairy cows. J. Dairy Sci. 91:3190-3200.

Batra, T. R., C. Y. Lin, A. J. McAllister, A. J. Lee, G. L. Roy, J. A Vesely, J. M. Wauthy, and K. A. Winter. 1987. Multitrait estimation of genetic-parameters of lactation curves in Holstein heifers. J. Dairy Sci. 70:2105-2111.

Ben Gara, A., B. Rekik, and M. Bouallegue. 2006. Genetic parameters and evaluation of the Tunisian dairy cattle population for milk yield by Bayesian and BLUP analyses. Livest. Sci. 100:142-149.

Bolormaa, S., J. E. Pryce, B. J. Hayes, and M. E. Goddard. 2010. Multivariate analysis of a genome-wide association study in dairy cattle. J. Dairy Sci. 93:3818-3833.

Buckley, F., K. O'Sullivan, J. F. Mee, R. D. Evans, and P. Dillon. 2003. Relationships among milk yield, body condition, cow weight, and reproduction in spring-calved Holstein-Friesians. J. Dairy Sci. 86:2308-2319.

Campos, M. S., C. J. Wilcox, C. M. Becerril, and A. Diz. 1994. Genetic parameters for yield and reproductive traits of Holstein and Jersey cattle in Florida. J. Dairy Sci. 77:867-873.

Clempson, A. M., G. E. Pollott, J. S. Brickell, N. E. Bourne, N. Munce, and D. C. Wathes. 2011a. Evidence that leptin genotype is associated with fertility, growth and milk production in Holstein cows. J. Dairy Sci. 94:3618-3628.

Clempson, A. M., G. E. Pollott, J. S. Brickell, N. E. Bourne, N. Munce, and D. C. Wathes. 2011b. Polymorphisms in the autosomal genes for mitochondrial function TFAM and UCP2 are associated with performance and longevity in dairy cows. Animal 5:1335-1343.

Clempson, A. M., G. E. Pollott, J. S. Brickell, and D. C. Wathes, 2012. Associations between bovine IGFBP2 polymorphisms with fertility, milk production, and metabolic status in UK dairy cows. Anim. Biotechnol. 23:101-113.

Crowe, M. A. 2007. Fertility in dairy cows-The conference in perspective. Pages 175-179 in Fertility in Dairy Cows: Bridging the Gaps. M. D. Royal, N. C. Friggens, and R. F. Smith, ed. Br. Soc. Anim. Sci., Edinburgh, UK.

de Vries, M. J., and R. F. Veerkamp. 2000. Energy balance of dairy cattle in relation to milk production variables and fertility. J. Dairy Sci. 83:62-69.

Evans, R. D., M. Wallace, L. Shallooa, D. J. Garrick, and P. Dillon. 2006. Financial implications of recent declines in reproduction and survival of Holstein-Friesian cows in spring-calving Irish dairy herds. Agric. Syst. 89:165-183.

Farhangfar, H. 2002. A phenotypic and genetic study of lactation traits in Iranian Holstein cows. PhD Thesis. University of Newcastle upon Tyne, Newcastle upon Tyne, UK.

Fulkerson, W., J. Wilkins, R. C. Dobos, G. T. M. Hough, M. E. Goddard, and T. Davison. 2001. Reproductive performance in Holstein-Friesian cows in relation to genetic merit and level of feeding when grazing pasture. Anim. Sci. 73:397-406.

Gilmour, A. R., B. J. Gogel, B. R. Cullis, and R. Thompson. 2009. ASReml User Guide Release 3.0. VSN Int. Ltd., Hemel Hempstead, UK.

Haile-Mariam, M., P. J. Bowman, and M. E. Goddard. 2003. Genetic and environmental relationship among calving interval, survival, persistency of milk yield and somatic cell count in dairy cattle. Livest. Prod. Sci. 80:189-200.

Hare, E., H. D. Norman, and J. R. Wright. 2006. Trends in calving ages and calving intervals for dairy cattle breeds in the United States. J. Dairy Sci. 89:365-370.

Jamrozik, J., G. Jansen, L. R. Schaeffer, and Z. Liu. 1998. Analysis of persistency of lactation calculated from a random regression test day model. Interbull Bull. 43:64-69.

Kadarmideen, H. N., R. Thompson, M. P. Coffey, and M. A. Kossaibati. 2003. Genetic parameters and evaluations from single- and multiple-trait analysis of dairy cow fertility and milk production. Livest. Prod. Sci. 81:183-195.

Kadarmideen, H. N., R. Thompson, and G. Simm. 2000. Linear and threshold model genetic parameter estimates for disease, fertility and production traits in UK dairy cattle. Anim. Sci. 71:411-420.
Kelm, S. C., A. E. Freeman, and NC-2 Technical Committee. 2000. Direct and correlated responses to selection for milk yield: Results and conclusions of regional project NC-2, "Improvement of dairy cattle through breeding, with emphasis on selection." J. Dairy Sci. 83:2721-2732.

LeBlanc, S. 2010. Assessing the association of the level of milk production with reproductive performance in dairy cattle. J. Reprod. Dev. 56(Suppl.):S1-S7.

Lucy, M. C. 2001. Reproductive loss in high-producing dairy cattle: Where will it end? J. Dairy Sci. 84:1277-1293.

Muir, B. L., J. Fatehi, and L. R. Schaeffer. 2004. Genetic relationships between persistency and reproductive performance in first-lactation Canadian Holsteins. J. Dairy Sci. 87:3029-3037.

Norman, H. D., J. R. Wright, S. M. Hubbard, R. H. Miller, and J. L. Hutchison. 2009. Reproductive status of Holstein and Jersey cows in the United States. J. Dairy Sci. 92:3517-3528.

Oikonomou, G., K. Angelopoulou, G. Arsenos, D. Zygoyiannis, and G. Banos. 2009. The effects of polymorphisms in the DGAT1, leptin and growth hormone receptor gene loci on body energy, blood metabolic and reproductive traits of Holstein cows. Anim. Genet. 40:10-17

Olori, V. E., T. H. E. Meuwissen, and R. F. Veerkamp. 2002. Calving interval and survival breeding values as measure of cow fertility in a pasture-based production system with seasonal calving. J. Dairy Sci. 85:689-696.

Pollott, G. E. 2000. A biological approach to lactation curve analysis for milk yield. J. Dairy Sci. 83:2448-2458.

Pollott, G. E. 2004. Deconstructing milk yield and composition during lactation using biologically-based lactation models. J. Dairy Sci. $87: 2375-2387$.

Pollott, G. E. 2009. Genetic parameters of a biological lactation model: Early lactation and secretion rate traits of dairy heifers. Animal 3:1085-1093.

Pollott, G. E., and M. P. Coffey. 2008. The effect of genetic merit and production system on dairy cow fertility, measured using progesterone profiles and on-farm recording. J. Dairy Sci. 91:3649-3660.

Pollott, G. E., and E. Gootwine. 2000. Appropriate mathematical models for describing the complete lactation of dairy sheep. Anim. Sci. 71:197-207.

Pollott, G. E., and E. Gootwine. 2001. A genetic analysis of complete lactation milk production in Improved Awassi sheep. Livest. Prod. Sci. $71: 37-47$.

Pryce, J. E., M. P. Coffey, and S. Brotherstone. 2000. The genetic relationship between calving interval, body condition score and linear type and management traits in registered Holsteins. J. Dairy Sci. 83:2664-2671.

Pryce, J. E., M. P. Coffey, S. Brotherstone, and J. A. Woolliams. 2002. Genetic relationships between calving interval and body condition score conditional on milk yield. J. Dairy Sci. 85:1590-1595.

Pryce, J. E., M. P. Coffey, and G. Simm. 2001. The relationship between body condition score and reproductive performance. J. Dairy Sci. 84:1508-1515.

Pryce, J. E., M. Haile-Mariam, K. Verbyla, P. J. Bowman, M. E. Goddard, and B. J. Hayes. 2010. Genetic markers for lactation persistency in primiparous Australian dairy cows. J. Dairy Sci. 93:2202-2214.

Pryce, J. E., B. L. Nielsen, R. F. Veerkamp, and G. Simm. 1999. Genotype and feeding system effects and interactions for health and fertility traits in dairy cattle. Livest. Prod. Sci. 57:193-201.

Royal, M. D., J. A. Woolliams, and A. P. F. Flint. 2002. Estimation of genetic and phenotypic associations between endocrine and traditional fertility parameters and production traits in HolsteinFriesian dairy cows. J. Dairy Sci. 85:958-967.

Sargent, F. D., V. H. Lytton, and O. G. Wall Jr. 1968. Test interval method of calculating Dairy Herd Improvement Association records. J. Dairy Sci. 51:170-179.

SAS Institute. 2003. User's Guide, Release 9.1. SAS Inst., Cary, NC.

Sewalem, A., G. J. Kistemaker, and F. Miglior. 2010. Relationship between female fertility and production traits in Canadian Holsteins. J. Dairy Sci. 93:4427-4434. 
Shanks, R. D., P. J. Berger, A. E. Freeman, and F. N. Dickinson. 1981. Genetic aspects of lactation curves. J. Dairy Sci. 64:1852-1860.

Silvestre, A. M., F. Petim-Batista, and J. Colaco. 2005. Genetic parameter estimates of Portuguese dairy cows for milk, fat, and protein using a spline test-day model. J. Dairy Sci. 88:1225-1230.

Varona, L., C. Moreno, L. A. G. Cortes, and J. Altarriba. 1998. Bayesian analysis of Wood's lactation curve for Spanish dairy cows. J. Dairy Sci. 81:1469-1478.

Wall, E., S. Brotherstone, J. F. Kearney, J. A. Woolliams, and M. P. Coffey. 2005. Impact of nonadditive genetic effects in the estimation of breeding values for fertility and correlated traits. J. Dairy Sci. 88:376-385.

Wall, E., S. Brotherstone, J. A. Woolliams, G. Banos, and M. P. Coffey. 2003. Genetic evaluation of fertility using direct and correlated traits. J. Dairy Sci. 86:4093-4102.
Walsh, S. W., E. J. Williams, and A. C. O. Evans. 2011. A review of the causes of poor fertility in high milk producing dairy cows. Anim. Reprod. Sci. 123:127-138.

Wood, P. D. P. 1967. Algebraic model of lactation curve in cattle. Nature 216:164-165.

Wood, P. D. P., and P. N. Wilson. 1983. Some attributes of very highyielding British Friesian and Holstein dairy cows. Anim. Prod. $37: 157-164$.

Zwald, N. R., K. A. Weigel, W. F. Fikse, and R. Rekaya. 2003. Identification of factors that cause genotype by environment interaction between herds of Holstein cattle in seventeen countries. J. Dairy Sci. 86:1009-1018. 